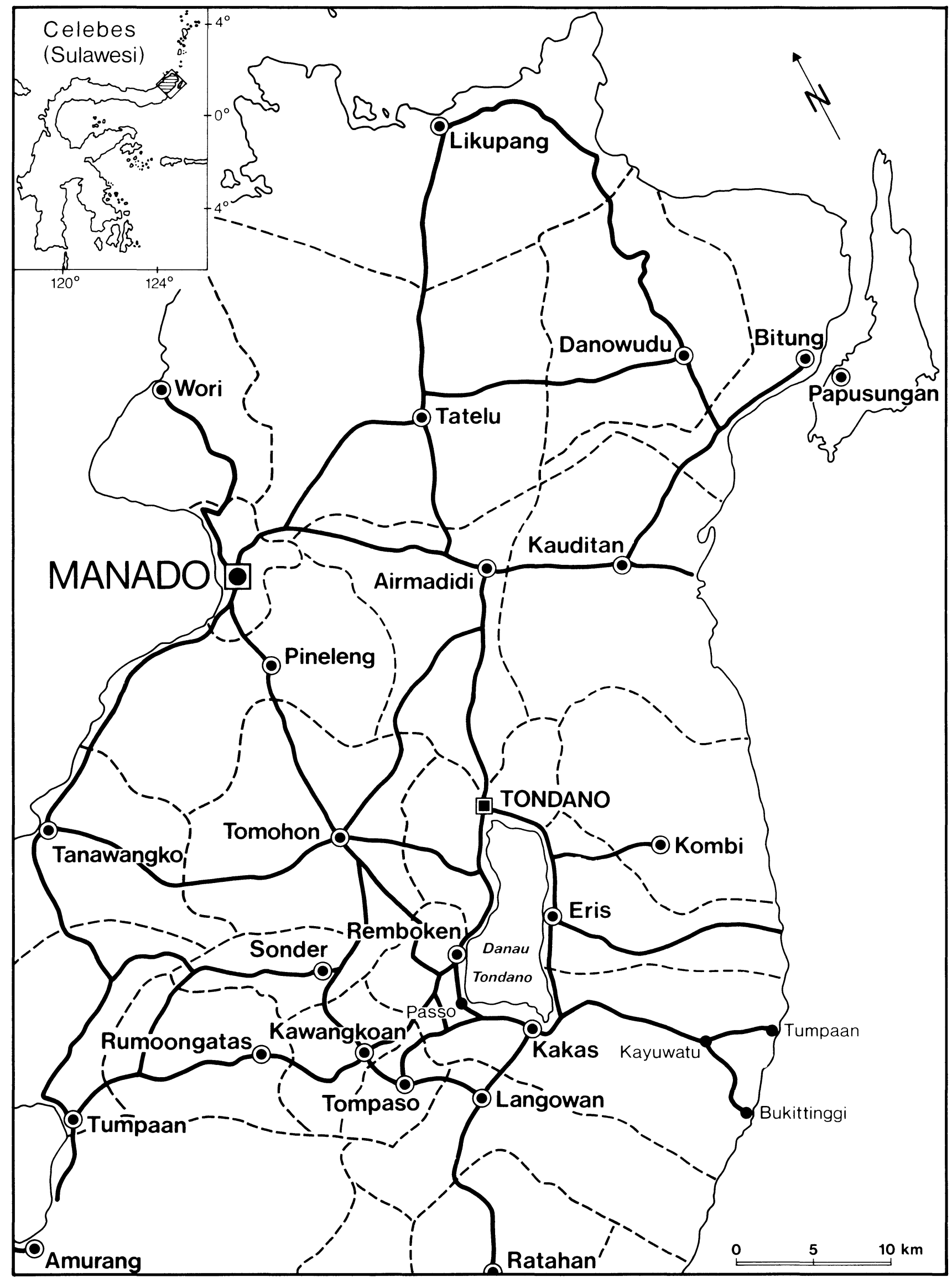

Kabupaten Minahasa 


\title{
SMALL-TOWN MARKETS AND THE URBAN ECONOMY IN KABUPATEN MINAHASA
}

\author{
Ulrich Mai
}

\section{Preface}

In recent years the informal sector of Third World economies has become a focus of research because of indications that it can provide a source of job opportunities. Particular attention has been paid to the field of small-scale trading in the rapidly expanding urban areas. Thus far, most studies of petty trade in Southeast Asia have been concerned with the cities, ${ }^{1}$ and little is known about present-day aspects of the phenomenon in small towns. ${ }^{2}$ It is clear, however, that those urban social problems stemming from the large-scale inmigration to the cities are in part a result of the worsening living conditions in the rural areas, and it is widely accepted that providing employment for the rural poor will thus moderate the problems of the urban poor.

Accordingly, in the summer of 1982, Geography and Sociology graduate students from Bielefeld University carried out field work on small-town markets in Minahasa, with the support of Universitas Sam Ratulangi, Manado. This article contains some of the results of that research. It aims to analyze small-town markets in kabupaten Minahasa with special regard to employment possibilities, under the classical assumption that transactions in small-town markets (in the sense of market places, pasar) widely reflect the local and even regional economies.

\section{The Regional Economy}

Except for a few factories in Manado and Bitung, which mainly process agricultural products, there is little industry in kabupaten Minahasa. Although--as all over Indonesia--an increasing proportion of people work in community, social, and

1. See, for example, T. G. McGee, "Hawkers in Selected Southeast Asian Cities. The Comparative Research Study Outline, Findings and Policy Recommendations" (Report to the Conference on the'Role of Marginal Distribution Systems in Development, sponsored by the International Development Research Center of Canada, Kuala Lumpur, Malaysia, September 23-26, 1975), and C. Wong, "The 'Little Businessmen' of Bukit Timah: A Study of the Economic, Social and Political Organization of Traders in a Market Complex in Singapore" (PhD thesis, University of Kent at Canterbury, 1979).

2. Exceptions with regard to the situation in Java in the late 1950 s can be found in Clifford Geertz, Peddlers and Princes (Chicago: University of Chicago Press, 1963), and Alice G. Dewey, Peasant Marketing in Java (New York: Free Press of Glencoe, 1962). See also P. Kuwinpant, "Organizational Aspects of Markets in Southeast Asia: A Comparative Study" (Paper read at the Second Thai-European Research Seminar, Saarbrücken, June 14-18, 1982) for markets in Thailand. 
personal service sectors (13.7 percent in Minahasa in 1971), ${ }^{3}$ both rural and urban populations are still heavily dependent on agriculture for their main source of income. The kabupaten has extremely fertile volcanic soil and a long history of growing spices for the world market. Today copra (in the northern part of Minahasa) and cloves (in the mountainous areas) are its major cash crops. Cloves, which provide the characteristic flavor of the Indonesian kretek cigarette, dominate the region's agriculture. In cultivating cloves, growers get better prices for less work and less capital investment, so that more and more farmers are abandoning sawah cultivation to grow them. Particularly around Lake Tondano, traditionally a rice surplus region, there is an expanding area of idle sawah, or sawah turned into grazing fields for horses. One hectare of cloves earns approximately 10 million rupiah every three years, so an average peasant family can apparently live on two hectares of clove gardens, particularly if they retain some sawah for subsistence.

There may, however, be crises. Cloves produce a large harvest only once every three years. (In the two intervening years, only 10 percent of that harvest is produced.) Furthermore, young clove trees cannot be harvested for the first five years after planting. This situation can result in severe cash shortages, which may be disastrous if no basis for agricultural subsistence remains. Even if there is such a basis, in the form of rice, maize, and cassava fields, during long dry periods (as in 1982 when there was practically no rain for more than five months), noticeable shortages occur in basic food supplies for home consumption or marketing. This is particularly so with rice, which, after a long dry period, may yield only one harvest in a year rather than the usual three (five in two years). Monetary crises may, of course, also be caused by urgent expenses required for such occasions as a christening feast, a wedding, or a funeral.

The dominant position of cash crops in the regional economy, and thus the integration of that economy into the world market, has generated a rising demand for money. In kecamatan Kakas, at the southern end of Lake Tondano, there are very few landless peasants, in contrast to the situation on Java, and the main source of subsistence and monetary income is still agricultural in character. Job opportunities in other sectors, which might provide additional money, such as in construction, are extremely scarce and are open mainly to males. Opportunities for agrarian wage labor are also very scarce. Most agricultural land units are small, and the families owning them usually farm the land themselves, or with the help of the mapalus (mutual aid association). The few big farms prefer to employ temporary migrant wage laborers from the Sanghir Islands.

Money shortages have to be met primarily by selling and trading the surplus of agricultural production, though there are, of course, a number of other activities through which a person can supplement his/her income, such as, for example, driving a suzuki--mini taxi, or a coach (bendi), working in a sand pit, sewing, or prefabricating parts for the thatched roofs which still exist in the region.

\section{The Market--Classical Assumptions}

In contrast to job opportunities in other fields, access to working in the market is free. In fact, anybody in need of cash may, without any restriction of age, education, or even experience, seek employment in the pasar. The "right to make a living" through the market ${ }^{4}$ is commonly respected. P. Kuwinpant has stated that,

3. See Table 3.28 in Gavin W. Jones, The Population of North Sulawesi (Yogyakarta: Gadjah Mada University Press, 1977), p. 98.

4. Dewey, Peasant Marketing in Java, p. 82. 
regardless of the size of the enterprise, "businesses in the market are not petty trade but, indeed, lucrative and crucial for certain classes of people, " 5 and he refers to the market place as demonstrating "aspects of a social welfare system." 6

While authors writing on the markets of Southeast Asia do not agree as to whether the pasar is mainly personal or impersonal in character, ${ }^{7}$ it is widely accepted that traditional markets function on the basis of reciprocal obligation and mutual trust between traders and buyers, who are often connected by long-term relationships. The density of the market as a social and economic network is indicated by the common habit of granting credit. Such a system demands some regularity and stability in the relationship between the two parties (often through kinship or friendship) in order to reduce the risk inherent in every transaction. ${ }^{8}$ With these characteristics in mind, and because of its high solidarity and ability to provide jobs and share surpluses, Kuwinpant refers to the market in Southeast Asia as a "moral community." 9

Furthermore, the market is regarded as a place where traders can gain experience and even the money needed to establish their own business outside the market, such as a shop (toko). In other words, the market seems to provide an opportunity for everybody to gain the basic economic knowledge needed to embark on a more sophisticated, and, as far as material prospects are concerned, more promising, career in trade.

Labor in the market is, to a certain extent, divided along sexual lines, with males involved in most of the delivery of heavy commodities and in the trading of more valuable or higher-status goods, such as sea fish, meat, and most imported factory products. ${ }^{10}$ Women, however, form a much larger part of the market, around 90 percent of all retailers. There are various reasons for this overrepresentation, particularly in the food sector. One of the most important is that men have a dominant position in the political and religious life of Minahasa and also in its agriculture, while job opportunities for women, outside the market, are extremely scarce. ${ }^{11}$ Although many of the men questioned maintained that they were embarrassed (malu) to trade in a small-town market, this does not seem to be a major reason for the high proportion of women there. Rather--apart from food retailing, which is considered closely related to the women's usual domestic subsistence work --their preponderance in the small-town markets reflects the fact that trading in these markets is primarily a matter of earning additional money within the household, while most of the family income is gained from agriculture. In fact, when trading is the main occupation of a household, i.e., where it is a permanent, not part-time or occasional, occupation, it is usually the males in the family who are the traders. In general, then, most of the trading in the market places provides only a supplemental income; yet however small, this is usually of vital importance for most households.

5. Kuwinpant, "Organizational Aspects of Markets," p. 4.

6. Ibid., p. 1.

7. Ibid.

8. Cf. Dewey, Peasant Marketing in Java, pp. $104 \mathrm{ff}$.

9. Kuwinpant, "Organizational Aspects of Markets," p. 4.

10. Cf. Wong, "'Little Businessmen' of Bukit Timah."

11. Kuwinpant, "Organizational Aspects of Markets," pp. $7 \mathrm{ff}$. 


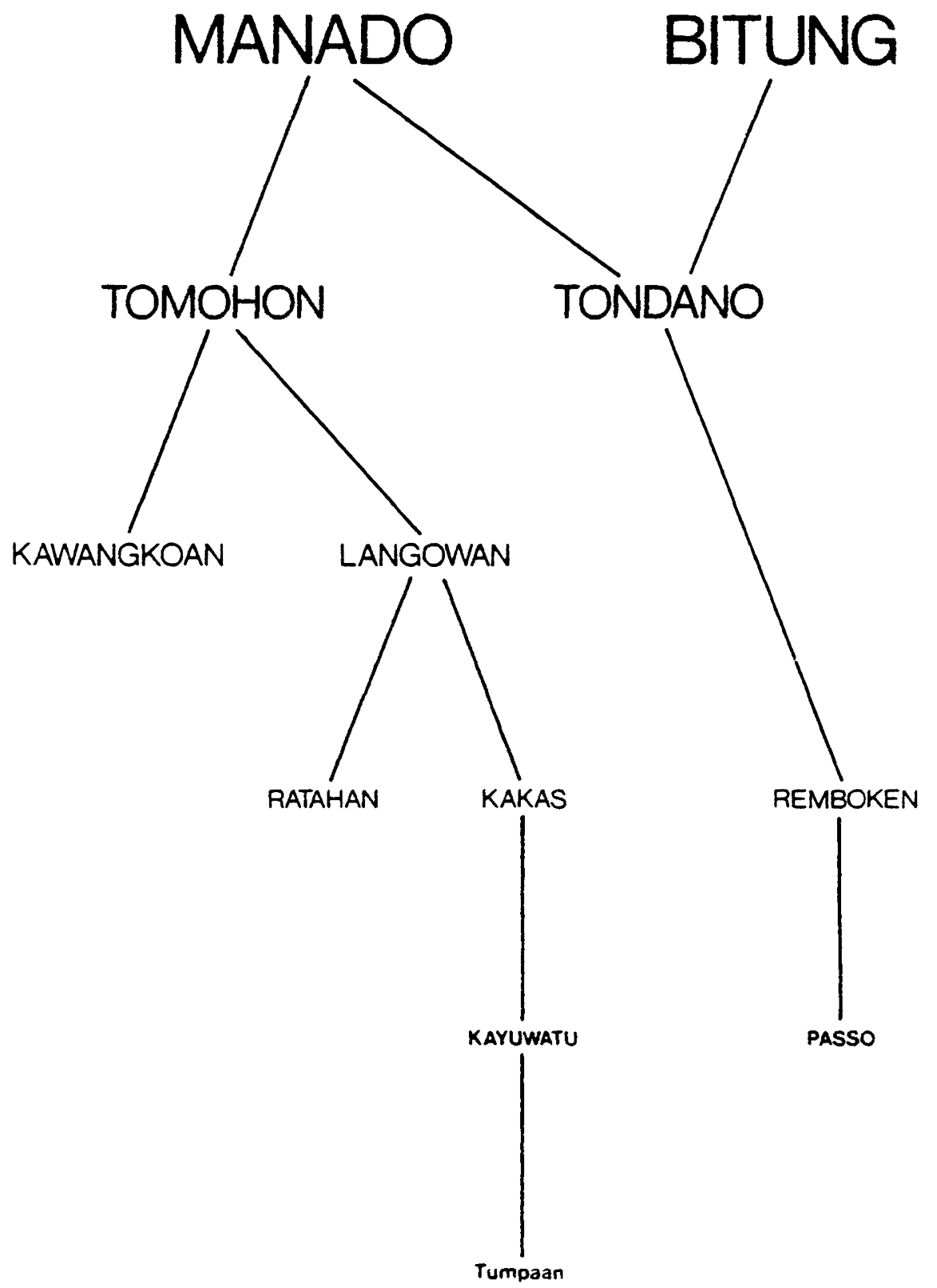

Figure 1 
According to Dewey and Geertz, the classical assumption is that further jobs can always be provided by intermediate trade. This assumption is based on the idea that inside a regional hierarchy of market places, commodities move up or down stepwise: factory-produced goods, most of which are imported, are gradually broken down as they move from the harbor to the largest market in the region, and from there, by stages, down to the smallest pasar. Agricultural commodities in the process of bulking are shipped upward according to the same pattern. Such a stepby-step process, involving relatively short transportation distances between the markets, would indeed allow for a great number of middlemen to exist between producer and consumer. ${ }^{12}$ As might be expected, however, the situation in Minahasa, as we perceived it, diverged widely from this pattern.

\section{The Regional System of Market Places in Minahasa}

Let us assume that a farmer, living in Tumpaan, which is a small village on the southern coast of Minahasa, decides to buy certain consumer goods, such as hardware, for his household. To do this, he will first try the Kayuwatu market, which is only a few kilometers away: if he is unsuccessful there, he will go to Kakas, the closest of the small-town markets; then to Langowan, to Tomohon, and finally to Manado, the provincial capital. In other words, he would move up the hierarchy of market places in Minahasa as far as necessary to obtain his needs. This implies that, inside the market hierarchy, the different levels of market places are defined by the size of the market, and that the higher the level, the larger the number and variety of consumer goods available. There is a further corollary that the higher the level of the market place, the larger the town where it is located, and the more numerous the population it serves, until the peak is reached at Manado. Figure 1 gives an idea of the relationship between the different levels of markets, with special reference to the four small towns where our field work was conducted in the summer of 1982 (Remboken, Kakas, Langowan, Kawangkoan). It may be arguable whether the small-town markets which are assumed to be on the same level are in fact of equal importance. There is no doubt, however, about the relative position of the markets inside the single branches of the hierarchy.

\section{Trading Patterns}

\section{The Trading of a Cash Crop--the Case of Cloves}

Until a few years ago, cloves, like ordinary agricultural products, were sold by small traders or by the peasants themselves on the local market. Today, however, the trade in cloves is subject to rigid government regulations. In summer 1982, for example, the farmers received a guaranteed price of 7,500 Rp. per kilogram. The local KUD (Kooperasi Unit Desa, Rural Unit Cooperative), of which almost all farmers are members, collected the entire harvest, shipped it to the regional KUD organization, which finally sold it at an auction. At this point the bulk of the harvest is usually purchased by PAP (Pedagang Antar Pulau, Inter-Island Traders), an almost exclusively Chinese-owned corporation, which is connected to the kretek cigarette industry on Java. In 1982, however, the local KUD of Kakas ran out of money, and consequently most of the area's clove harvest went directly to PAP, presumably for lower prices. For this purpose PAP employs one or two agents per kecamatan who cooperate closely with approximately ten local traders (tibo), all of whom, during the time the KUD was not operating, contacted the

12. Up to twelve, depending on the type of goods, according to Geertz, Peddlers and Princes, p. 31. 
peasants directly to buy their cloves. In such a situation, the peasants, who often lack detailed market information, come under pressure from the PAP's agents. This particularly applies to those peasants who are in desperate need of money and have to accept prices below even the guaranteed level. In order to meet government regulations whereby all clove transactions have to involve the KUD, the PAP (with the farmers' cooperation) arranges fake auctions of the cloves.

It is quite obvious that today clove marketing--whether or not it is carried out in accordance with current regulations--needs fewer people than were involved in the traditional trading methods. Such methods in fact are now practically obsolete. The current method of cash-crop marketing, of course, creates some new jobs, particularly in the KUD administration, including ones involving storage and transportation. However, far more local and regional small traders, who used to purchase and sell cloves, have lost their main source of income, since a large proportion of the harvest is shipped directly from the producer to the large consumer corporations, bypassing the small-town markets. Precisely the same procedure, with precisely the same consequences, applies to the marketing of copra, the other major cash crop of Minahasa.

\section{Trading in Factory-Produced Goods}

Before being traded within Minahasa, almost all factory-produced goods are concentrated in Manado or Bitung, the two largest cities of North Sulawesi. These are also the region's largest ports and the places where Minahasa's few factories are located.

In contradiction to classical theory, however, there is again hardly any stepwise consignment of factory-produced commodities down the hierarchy of market places. Instead, marketing these goods is widely controlled by Indonesians of Chinese descent, who have a dense system of stores throughout Minahasa. Only the smallest towns of the region, such as Kakas and Remboken, do not belong to this system, for their stores carry scarcely more goods than the local markets. Virtually all the other stores now receive direct deliveries from some dominant Chinese wholesalers or toko owners in Manado or Bitung.

And yet, there is still a niche where small-market traders are able to participate in marketing factory-produced goods. Since, in general, as one goes down the hierarchy of market places, prices tend to increase, there is always an opportunity to make a small profit by purchasing a certain commodity, let us say, in Kawangkoan or Langowan, and selling it in a market at a lower level, such as at Remboken or Kakas. However, the small entrepreneur is faced with fierce competition from the stores, and, although his principal occupation is trading in these factory-produced goods, his prospects for making a profit are poor. Many of these small traders invest a considerable amount of money to ensure they can maintain a sufficient variety of supplies to attract customers. Since they have to ask for credit to achieve this position, they become dependent on the toko owner, who provides the goods and finally dictates higher prices, which, in turn, further reduces the small trader's profits.

Strictly speaking, traders in industrial goods exist at the sufferance of the shop owners, who supply the commodities and regard the traders merely as useful agents who can provide the store owners with an opportunity to make additional income and extend their own commercial territory. Since the stores seem to be tightening their grip on the market, particularly by lowering their prices for imported mass products, and most customers from the villages and smallest towns, because of lower prices and better supply, are tending to visit larger market places than previously, job opportunities for small-town market traders are likely to decline further. 


\section{Trading in Foodstuffs}

Fresh food, such as vegetables, fruit, and meat, is usually traded as surplus of the subsistence production. The trading is done in two different ways: either the housewife does the trading herself on a part-time basis, in which case no intermediate trader is involved; or, and this holds true for most fresh food reaching small-town markets in Minahasa, the local village full-time intermediate traders (tibo) making use of long-term close personal relationships with the peasants, purchase their surplus and sell it in larger amounts to other traders connected with small-town markets. (These transactions usually take place in the village during the early morning hours of market days, or the previous afternoon.) Other tibo from even smaller markets in some cases take advantage of these price differences, to purchase the food, for example, in Langowan or Kawangkoan and sell it finally to the consumer in Kakas or Remboken. The instances where two tibo are involved between producer and consumer occur especially with food which is not too perishable (such as brown sugar, some fruit, coffee, sweet potatoes, sago powder, maize, and rice) and can be stored over a longer period and withstand longer shipment time.

As irrigation is needed to harvest some vegetables, particularly in the dry season, there are considerable regional disparities in vegetable production. For example, such areas as Ratahan and Modoinding in the sparsely populated southern part of the kabupaten show a remarkable surplus of vegetables. (Modoinding, incidentally, is a resettlement project where the economic emphasis is on rice and vegetable production partly destined for the more densely populated regions of the province.) Tibo from various small towns in Minahasa of ten journey by public Datsun trucks for up to three hours each way every day to Ratahan or Modoinding, where they purchase vegetables for their local markets. The passengers on these trucks are often almost exclusively tibo, who, despite considerable transportation costs, still gain some profit.

Today Minahasa is a rice-deficit area, due in large part to the rapid extension of cash-crop production and to a lesser extent to population increase. Thus, imported as well as regionally produced rice is sold in the market places according to different trading methods. Imported rice is treated very much like factory-produced commodities, with consignments reaching the local region directly from Manado and Bitung. Locally and regionally produced rice, however, is treated like fresh food, with at least two tibo usually involved in the marketing, if the peasant or his wife do not themselves trade their rice. Towards the end of the dry season, especially if it has been exceptionally long, rice is in extremely short supply in the markets and is more expensive. A higher proportion of the rice is also imported, so fewer rice tibo are involved. This indicates how employment opportunities in the market can be subject to seasonal conditions. Small traders have little possibility of compensating for their losses by trading in alternative goods, such as maize and cassava, because these foodstuffs earn lower returns and attract smaller demand, as most local households grow them in their own gardens.

At present there are plans to reorganize regional rice trading to conform to the pattern for copra and cloves, so that all supplies would be channeled through the KUD and the farmer would receive a guaranteed price. Such plans, of course, would have ruinous consequences for the regional small traders.

Rice and fish constitute Minahasa's basic foods. Fresh water fish are taken from special ponds and from Lake Tondano, where the water is still relatively clean. In Kakas, at the southern end of the lake, there are approximately 200 boats used for fishing, half of them going out daily, and twenty motorized boats. Very few of 
the owners are fishermen on a permanent full-time basis. Fishing in the lake is usually carried out to acquire supplementary income to that derived from farming.

During the early morning hours tibo usually follow the fishermen on to the lake to collect their catch, conducting the transaction on the lake. Some of the tibo, in order to get hold of more and better fish, even use motor boats. On the other hand, some fishermen still have relations with certain tibo which are exclusive in character, in that they sell the whole catch to one or a limited number of tibo. This does not exclude the possibility, particularly if the prices offered are too low, of the wives of the fishermen taking the catch to the market places themselves.

Marketing lake, as opposed to sea, fish is a thoroughly female business. Lake fish traders add considerably to the characteristic picture of the Minahasa market: in the morning they usually arrive in a group at the market place, always occupying the same corner. There they stand closely together or squat over their fish bowls, exchanging market information as well as gossip, and always prepared to assist in any transaction going on. The impression of solidarity and collectivity, existing not only among the traders but also between them and their customers, is further strengthened when the customers, with friends or relatives among the tibo, intermingle with them. Since there are no stalls to function as a barrier, morphologically speaking, the customer cannot be distinguished from the tibo.

Sea fish are for sale in practically all Minahasa markets, with small fish (e.g., teri stolephorus) constituting the major food in the coastal regions and a major item of trade in the bigger markets. The situation is different with tuna (cakalang), the most valuable of the fish. Along the south coast almost all catches of tuna are landed in Bitung or Belang. Fishing is carried out almost exclusively by a few corporations which own relatively large ships manned by up to thirty crew members. (According to the regulations, tuna may only be caught with fishing rods, nets not being permitted.)

Tibo from around the region buy the tuna at the auction in Bitung and Belang and ship them, often by truckloads, to the larger market towns, where other traders distribute them. Much social prestige is attached to the tuna trade, and it is a highly specialized and more capitalized business than the trade in other sea fish. It is thus dominated more completely by men. In the small-town markets these tuna traders draw attention to their wares by shouting and aggressive sales strategies.

As far as job opportunities and the downward flow from the two harbors and auction centers are concerned, tuna trading closely resembles the trade in factoryproduced goods. Unlike consumer goods, however, tuna reaches even the smallest town and village markets in Minahasa. This is partly because the fish is traditionally smoked and dried to improve its durability, and it can thus be stored and transported for a longer time and over longer distances than fresh fish, for which there are no cold-storage facilities.

\section{Structural Changes in Small-town Markets}

In contradiction to classical theory, there is today in Minahasa hardly any stepwise up-and-downward movement of commodities through a "chain of markets." 13 As transactions are fewer, there are, accordingly, fewer opportunities for trading in the market. More common today are direct consignments, which bypass many of the markets in the traditional hierarchy. This development is caused by various factors :

13. Dewey, Peasant Marketing in Java, p. xviii. 


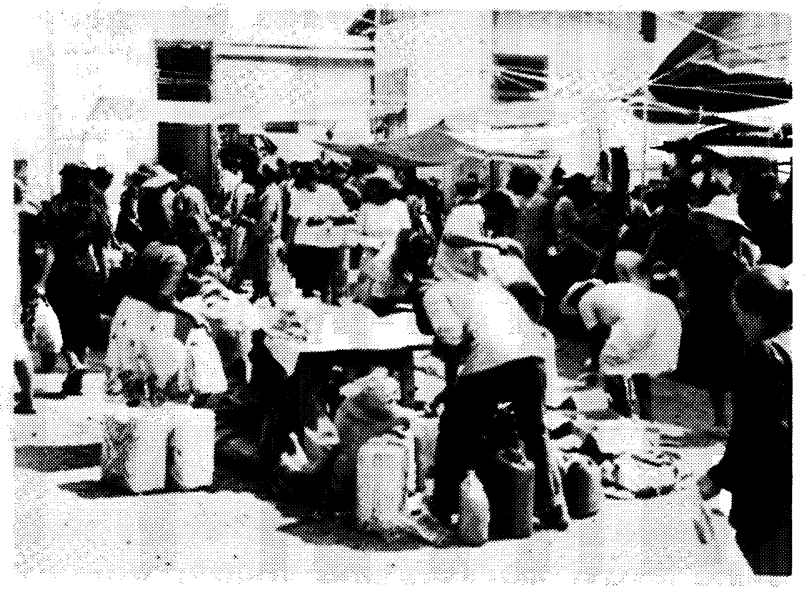

Traders in Rice, Maize, and Coconut Oil

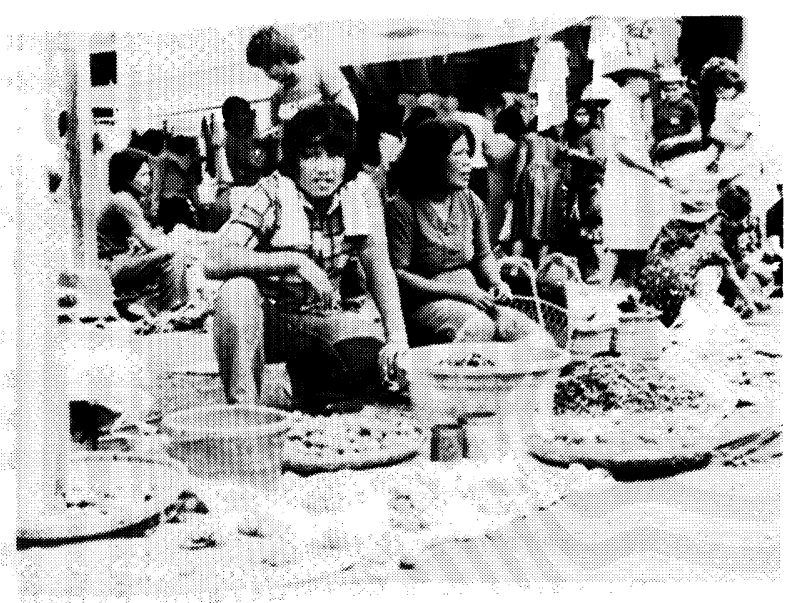

Traders in Vegetables

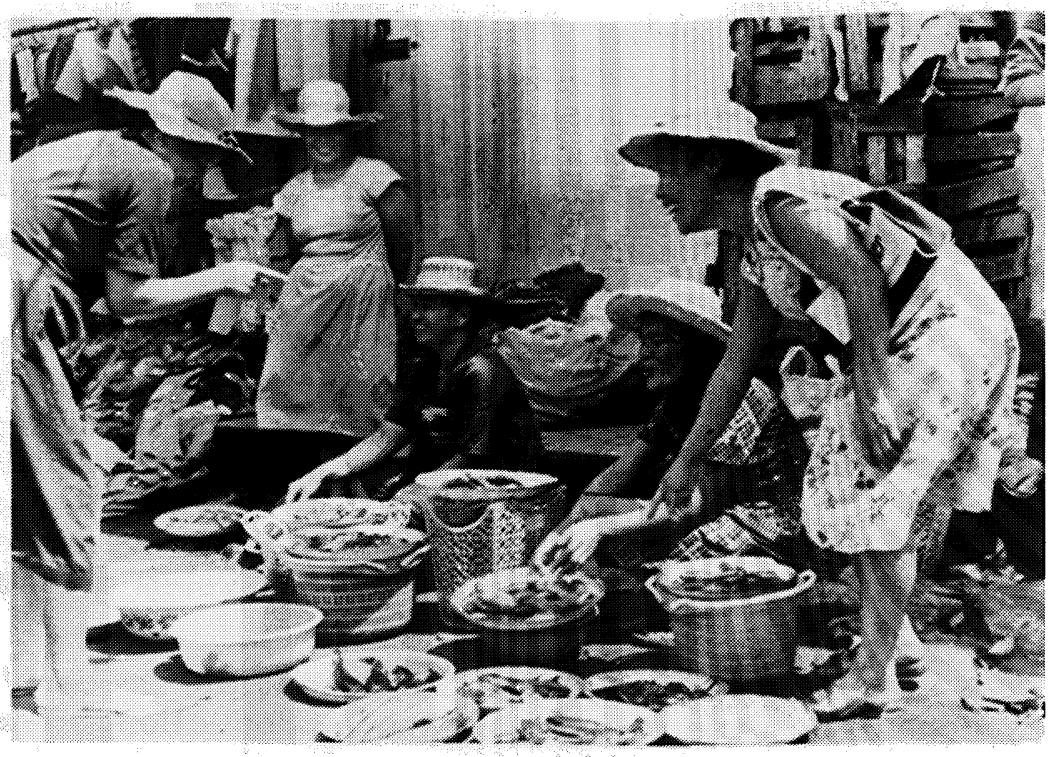

Lake Fish Traders

Kakas Market Place

a) The different mode of primary production. This is characterized by a considerable expansion of cash-crop production and the capitalization of at least tuna fisheries, developments which have induced a remarkable centralization in the regional trade. The funnel-like upward movement of cash crops, in particular, leaves many traders without a job.

b) Further integration of the region into the world market and an accompanying increase in demand for factory-produced goods are being accelerated by means of a well-organized and centralized trading system, with many traders now dependent 
on a few major outlets in the political and commercial centers (Manado/Bitung). Within this system direct commodity movements are necessary to reduce storage and transportation costs.

c) Better roads and the common use of Japanese mini-taxis and pickups have considerably improved accessibility to markets. This often has the consequence of attracting to the larger towns customers who used to visit their local village or small-town markets only. Thus, village and small-town markets are losing customers, and are being restricted more and more to trading only in fresh food and the occasional factory-produced goods. The availability of relatively cheap public transportation also enables many small peasant households to participate in trading at the market, even if it is far away, and thus to supplement their income, without becoming migrants.

d) Capitalization and the logic of trade profit have created a situation where trade is concentrated to a considerable extent in the larger markets and shops, where a wide variety of consumer goods in particular are available. At the same time, at the lower end of the hierarchy markets and small shops seem to be restricted to performing complementary functions. This implies that rural areas and small towns. will become increasingly dependent on services and goods provided by external agents located in a few larger towns. This regional peripheralization is further aggravated by higher prices, decreasing communications among villages and small towns (because traffic is almost exclusively oriented towards superior central market places), and by a general lack of public investment in providing infrastructure for the small market places, including improvements for storage and other facilities.

e) Within small-town markets a changing structural dichotomy between small and large traders has developed:

Small traders, usually women, representing the "traditional" part of the market, belong to households which, apart from trade, derive their income from a variety of sources, including wage labor, some cash production, and subsistence production. Small traders are generally part of a system of reciprocal obligation and mutual trust, and trading is commonly done on the basis of long-standing personal relations, thus reducing the risk of loss. Easily accessible to everybody, the traditional small-town market constitutes a kind of welfare system providing economic security and social cohesion for many. ${ }^{14}$

Large traders, who are mostly male and represent the "modern" part of the market, usually depend on little or no subsistence production. Trading is their major source of monetary income, which they acquire through daily work on various markets and investing their money to increase their stock. Their relations with customers are more impersonal and casual than those of the small trader, in part because they are not integrated in to a local society. This distance is reflected in the fact that larger traders hardly ever extend credit. Needing larger markets to compensate for higher economic risks, large traders generally avoid village and small-town markets, and when they do trade there, display a general lack of cooperation and solidarity among themselves.

The changes in the trading patterns have been at the expense of social integration and cohesion, which in turn add a social and economic component to the regional peripheralization whereby the rural areas and small towns have lost their active function in the market system of Minahasa.

14. G. Elwert, H.-D. Evers, and W. Wilkens, Die Suche nach Sicherheit--Kombinierte Produktionsformen im sogenannten informellen Sektor, Working Paper No. 28, Sociology of Development Research Centre (Bielefeld: University of Bielefeld, 1982). 